\title{
Native Gold of the Borovik Ore Field, Republic of Macedonia (FYROM)
}

\author{
V. Stefanova ${ }^{a}$, A. V. Volkov ${ }^{b}$, T. Serafimovski ${ }^{a}$, and A. A. Sidorov ${ }^{b}$ \\ ${ }^{a}$ Goce Delcev Universtity, Stip, 2000 Republic of Macedonia (FYROM) \\ ${ }^{b}$ Institute of Geology of Ore Deposits, Petrography, Mineralogy, and Geochemistry, Russian Academy of Sciences, \\ Staromonetny per. 35, Moscow, 119017 Russia
}

Received July 17, 2014

\begin{abstract}
Mineralogical and geochemical study has shown that native gold from the Borovik ore field, Republic of Macedonia (FYROM) is homogeneous in composition, high in fineness, and contains appreciable admixtures of $\mathrm{Fe}$ and $\mathrm{Cu}$. The chemical composition of native gold does not depend on the morphology of gold grains that indicates closeness of primary source. The results are similar to previous data on gold geochemistry from the Borov Dol porphyry copper and the Plavica high sulfidation epithermal deposits. Electrum was found in placer gold neither in the Borovik ore field nor at the adjacent Plavica deposit. Pan sampling within porphyry copper and silver-gold high sulfidation epithermal deposits and ore fields allows identification and detailed study of the chemical composition and morphological features of native gold from deposits of these types. This procedure is recommended to be applied at prospect and prospect-and-evaluation works. The composition of native gold and morphology of gold grains predict high sulfidation epithermal mineralization in the Borovik ore field.
\end{abstract}

DOI: $10.1134 / \mathrm{S} 1075701515020063$

\section{INRODUCTION}

Mineralogical and geochemical study of native gold from impregnated porphyry copper and high sulfidation (HS) epithermal ores at most deposits is hampered because of the fine, frequently micron-scale grains and low $(0.1$ to $2.0 \mathrm{~g} / \mathrm{t})$ grades of this metal. Previous publications reported the results of the study of typical features of native gold from the Borov Dol porphyry copper and Palvica HS epithermal deposits in the Republic of Macedonia (Volkov et al., 2008; Stefanova et al., 2013). Native gold in pan samples selected from small ravines and creeks draining stockworks was studied at these deposits. This paper is focused on the results of studies of gold sampled by this procedure within the Borovik ore field.

\section{GEOLOGY OF ORE FIELD}

The Borovik ore field is located in the central Kratovo-Ztetovo ore district $60 \mathrm{~km}$ east of Skopje and $5 \mathrm{~km}$ northwest of the Palvica HS epithermal deposit (Fig. 1, insert). Base-metal mineralization was found within it in 1974-1975 as a result of areal prospecting by the Belgrade Geological Institute (Bogojevski, 1967).

The Kratovo-Zletovo ore district, spatially related to the homonymous volcanic area $\left(1200 \mathrm{~km}^{2}\right)$, located at the boundary between the Serbo-Macedonian Massif and Vardar ophiolite zone (Dumurdzanov

\footnotetext{
${ }^{1}$ Corresponding author: A.V. Volkov. E-mail: alexandr@igem.ru
}

et al., 2005), is distinguished by the zoned distribution of various type base-metal and precious metal mineralizations (Cifliganec et al., 1997). This volcanic area comprises products of Oligocene-Miocene calc-alkaline magmatism (andsite, dacite, and their tuffs are predominant), which were intruded by the Pliocene basalt dikes.

The Borovik ore field is a part of large volcanic structure (Turalevo caldera), within which a few volcanic edifices are located (Borovik, Golak, Gradiste) (Fig. 1). Andesite flows are intercalated with thin tuff beds. This sequence is intruded by dikes and necks of augite andesite and porphyrytic diorite. All volcanic rocks are strongly altered to form hydrothermal quartzite, argillic rocks (illite, kaolinite, sericite), and jarosite rocks. Quartz-alunite lithocap covers hilltops composed of hydrothermal quartzite.

The ore field is located in the zone of the Balkan deep NNW-trending lineament separating the Vardar ophiolite zone and Serbo-Macedonian intermediate massif (Cifliganec et al., 1997). Therefore, faults of a similar trend are predominant within it. Some faults are indicated by the bodies of hydrothermal quartzite. Numerous thermal springs located along the Povisnica Valley (borehole no. 3 has a debit of $50 \mathrm{~L} / \mathrm{s}$ and temperature of $50.8^{\circ} \mathrm{C}$ ) are caused by recent tectonic activity along feathering faults. According to chemical analysis, water is sulfate-hydrocarbonate. The ther- 


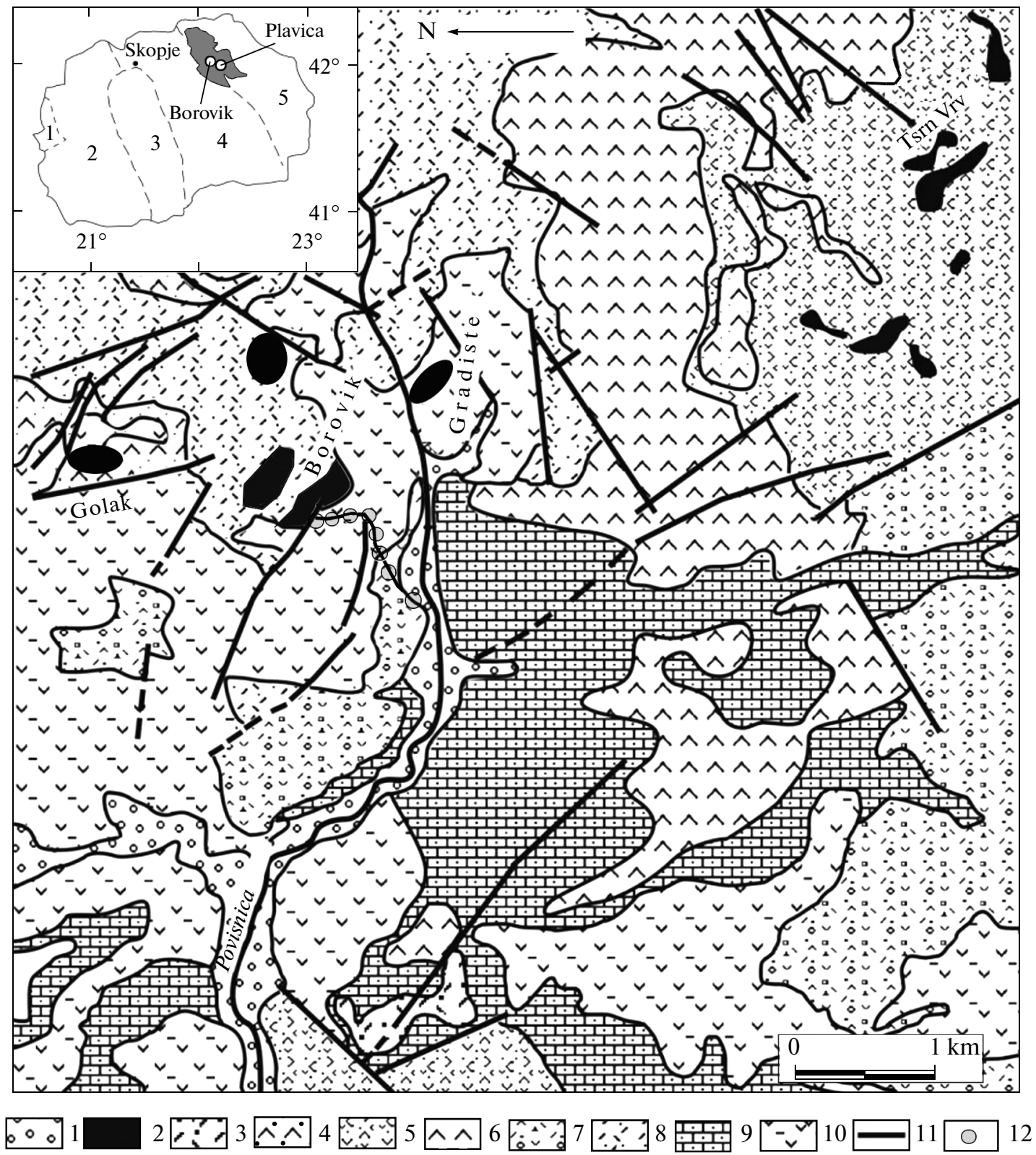

Fig. 1. Geological map of the Borovik ore field. Location of the Borovik deposit within the Kratovo-Zletovo volcanic field in the territory of Macedonia is shown in the insertion. (1) Alluvium, (2) hydrothermal quartzite, (3) hyaloandesite tuff, (4) hornblende-augite-biotite andesite, (5) andesite-dacite ignimbrite, (6) augite-hornblende-biotite-labradorite andesite, (7) volcanic breccia, (8) breccias and tuffstone, (9) green tuffstone, (10) hornblende-biotite-augite andesite, (11) faults, (12) location of pan sampling. In the insertion, numbers of zones correspond to the geological terranes of Macedonia, after Dumurdzanov et al. (2005): (1) Shukali-Krasta, (2) West Macedonian, (3) Pelagon Massif, (4) Vardar, (5) Serbo-Macedonian Massif.

mal springs are accompanied by the occurrences of native sulfur.

Pyrite is the most abundant ore mineral. It occurs in thin quartz veinlets of stockwork and altered wall rocks. In addition, chalcopyrite, galena, sphalerite, magnetite, hematite, molybdenite and occasional enargite, tetrahedrite, pyrrhotite, bornite, tenorite, cuprite, covellite, chalcocite, tennantite, cubanite, martite, malachite, and azurite were indentified in altered wall rocks.

According to the sampling of hydrothermal quartzite in the Borovik ore field, average $\mathrm{Cu}$ and Mo grade of is 0.1 and $0.025 \%$, respectively, and that of $\mathrm{Au}$ is 0.19-0.49 g/t (Bogojevski, 1967). The highest gold grade $(1.5 \mathrm{~g} / \mathrm{t})$ was identified in a sample from quartzsulfide stockwork. 


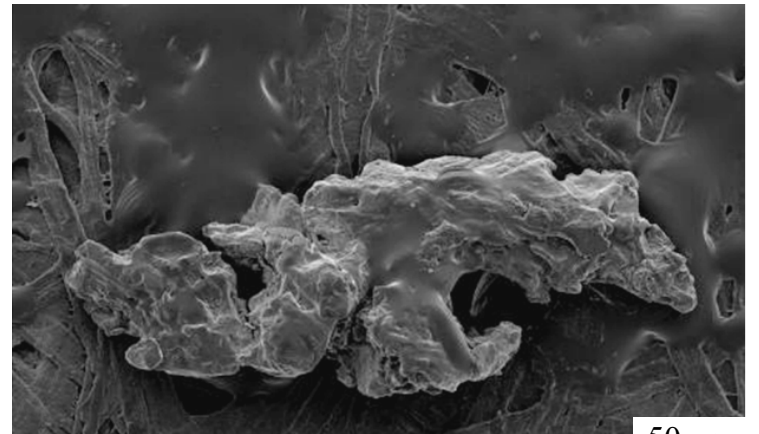

(a)
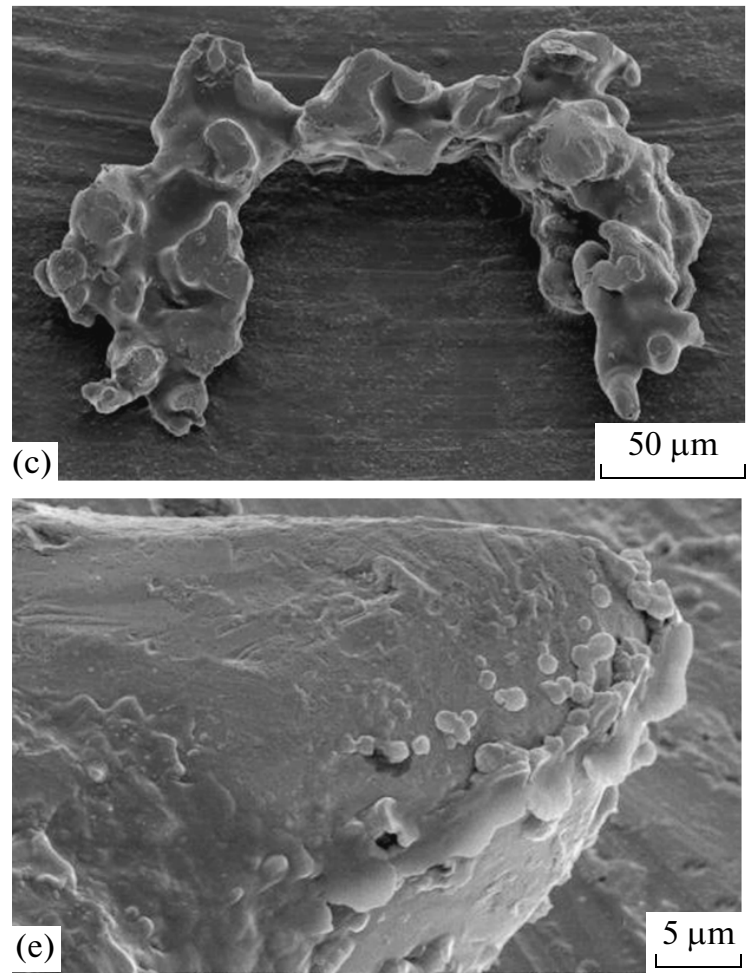
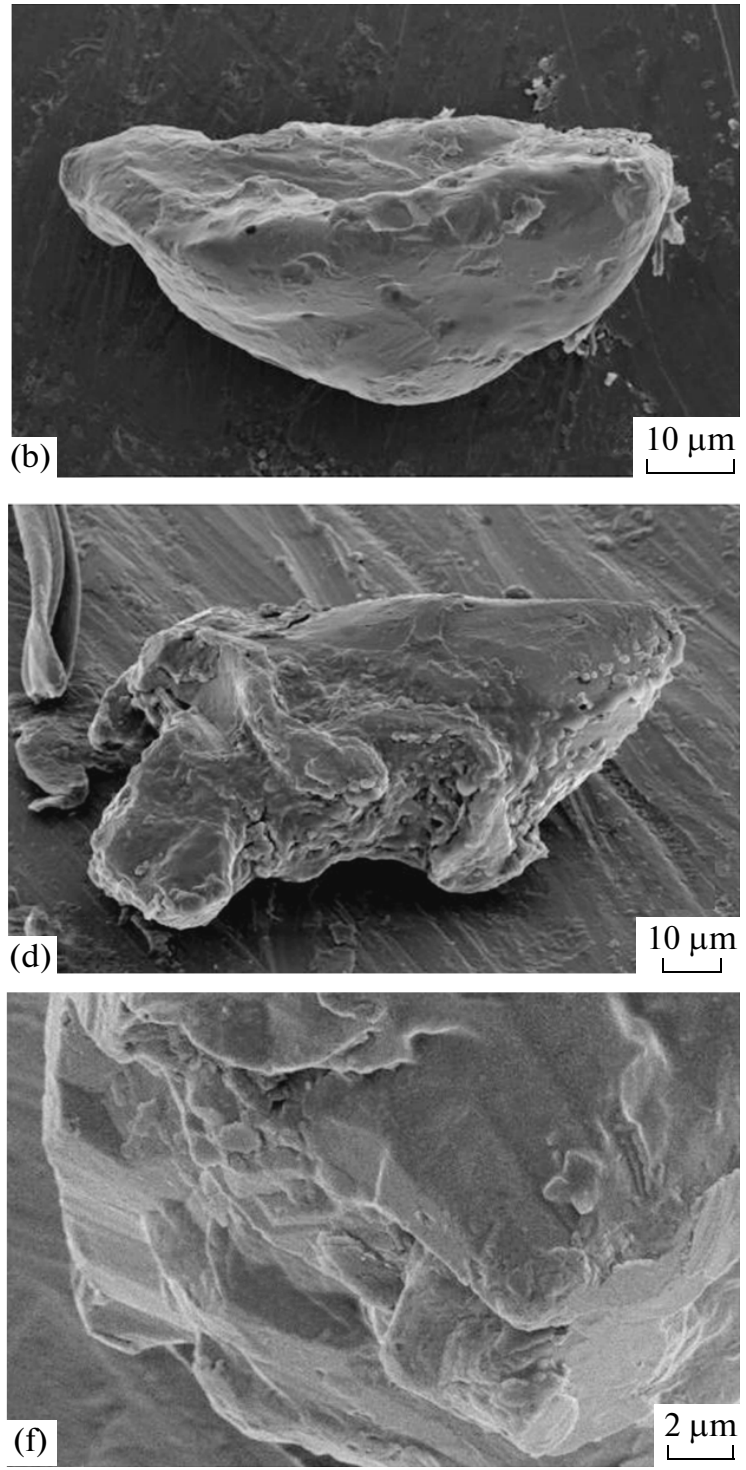

Fig. 2. Morphology of gold grains and their fragments from the Borovik ore field. (a) Crescent-shaped grain of native gold, (b) isomeric subrounded native gold, (c) dendritic native gold, (d) common elongated-isometric gold grains, (e) spherical aggregates of secondary minerals of the surface of the grain, magnified fragment of image d, (f) layered structure of native gold.

\section{MORPHOLOGY, COMPOSITION, AND STRUCTURE OF NATIVE GOLD}

The study of native gold from the Borovik ore field involved field and laboratory work. The former was pan sampling (according to the conventional procedure) of the creeks draining the ore field (Fig. 1). Eight pan samples were selected. Sixty-four grains of native gold were found in seven samples taken from the creek crossing the body of hydrothermal quartzite. In addition, feldspar, quartz, muscovite, epidote, abundant pyrite, and less frequent magnetite and chalcopyrite were identified in the pan samples. The number of native gold colors in the pan samples from the Borovik ore field is much higher than that at the other deposits studied in the Republic of Macedonia (Volkov et al., 2008; Stefanova et al., 2013).
The morphology of gold grains was studied on a JMS JEOL-5510 scanning electron microscope at the Electron Microscopy Laboratory of Chemistry Department, Sofia University, Bulgaria. The chemical composition of gold grains was determined on a JEOL LMS 35 CF electron microscope equipped with an X-Tractor Northern TN-2000 microprobe at the Sofia Institute of Photoprocesses, Bulgaria. The standards of the Jeol Company as pure metals were used for $\mathrm{Au}, \mathrm{Ag}, \mathrm{Cu}$, and $\mathrm{Fe}$. Detection limits for the elements $(\mathrm{Au}, \mathrm{Ag}, \mathrm{Cu}$, $\mathrm{Fe})$ are $0.01 \mathrm{wt} \%$.

According to electron microscopy, the grains of placer gold ranges from 30 to $250 \mu \mathrm{m}$ in size. Three morphological groups of gold grains are distinguished: isometric-elongated, irregular, and dendritic-laminar (Figs. 2a, 2b, 2c, 2d). It should be noted that very 
Electron microprobe data of gold from the Borovik ore field, wt \%

\begin{tabular}{|c|c|c|c|c|c|c|}
\hline \multirow{2}{*}{$\begin{array}{l}\text { Number } \\
\text { of sample }\end{array}$} & \multirow{2}{*}{ Point of analysis } & \multicolumn{5}{|c|}{ Components } \\
\hline & & Native gold & $\mathrm{Ag}$ & $\mathrm{Cu}$ & $\mathrm{Fe}$ & Total \\
\hline $\mathrm{BK}-2$ & $\begin{array}{l}1 \text { core } \\
2 \text { rim } \\
3 \text { rim } \\
\quad \text { Average content }\end{array}$ & $\begin{array}{l}98.52 \\
99.10 \\
99.02 \\
\mathbf{9 8 . 8 8}\end{array}$ & $\begin{array}{l}- \\
- \\
- \\
0\end{array}$ & $\begin{array}{l}0.71 \\
0.62 \\
0.46 \\
\mathbf{0 . 5 9}\end{array}$ & $\begin{array}{c}- \\
- \\
0.28 \\
\mathbf{0 . 2 8}\end{array}$ & $\begin{array}{l}99.23 \\
99.72 \\
99.76\end{array}$ \\
\hline $\mathrm{BK}-3$ & $\begin{array}{l}1 \text { core } \\
2 \text { rim } \\
3 \text { rim } \\
\quad \text { Average content }\end{array}$ & $\begin{array}{l}86.02 \\
92.34 \\
90.22 \\
\mathbf{8 9 . 5 2}\end{array}$ & $\begin{array}{r}12.91 \\
7.24 \\
9.09 \\
9.74\end{array}$ & $\begin{array}{l}0.34 \\
0.37 \\
0.39 \\
\mathbf{0 . 3 6}\end{array}$ & $\begin{array}{c}- \\
- \\
0.10 \\
\mathbf{0 . 0 3}\end{array}$ & $\begin{array}{l}99.27 \\
99.95 \\
99.80\end{array}$ \\
\hline BK-4/1 & $\begin{array}{l}1 \text { core } \\
2 \text { rim } \\
3 \text { rim } \\
\quad \text { Average content }\end{array}$ & $\begin{array}{l}99.02 \\
99.53 \\
99.41 \\
\mathbf{9 9 . 3 2}\end{array}$ & $\begin{array}{l}- \\
- \\
- \\
-\end{array}$ & $\begin{array}{l}0.48 \\
0.42 \\
0.56 \\
\mathbf{0 . 4 8}\end{array}$ & $\begin{array}{c}- \\
- \\
0.09 \\
\mathbf{0 . 0 3}\end{array}$ & $\begin{array}{r}99.50 \\
99.95 \\
100.06\end{array}$ \\
\hline $\mathrm{BK}-4 / 2$ & $\begin{array}{l}1 \text { core } \\
2 \text { rim } \\
3 \text { rim } \\
\quad \text { Average content }\end{array}$ & $\begin{array}{l}99.43 \\
99.24 \\
97.71 \\
\mathbf{9 8 . 7 9}\end{array}$ & $\begin{array}{l}- \\
- \\
-\end{array}$ & $\begin{array}{l}0.54 \\
0.38 \\
0.83 \\
\mathbf{0 . 5 8}\end{array}$ & $\begin{array}{c}- \\
0.17 \\
- \\
\mathbf{0 . 0 5}\end{array}$ & $\begin{array}{l}99.97 \\
99.79 \\
98.54\end{array}$ \\
\hline BK-4/3 & $\begin{array}{l}1 \text { core } \\
2 \text { rim } \\
\text { Average conten }\end{array}$ & $\begin{array}{l}98.68 \\
99.94 \\
99.46\end{array}$ & $\begin{array}{l}- \\
- \\
-\end{array}$ & $\begin{array}{l}0.47 \\
0.50 \\
0.77\end{array}$ & $\begin{array}{l}- \\
- \\
-\end{array}$ & $\begin{array}{r}99.15 \\
100.44 \\
100.23\end{array}$ \\
\hline $\mathrm{BK}-4 / 4$ & $\begin{array}{l}1 \text { core } \\
2 \text { rim } \\
3 \text { rim } \\
\quad \text { Average content }\end{array}$ & $\begin{array}{l}\mathbf{9 9 . 3 6} \\
99.08 \\
99.24 \\
99.54\end{array}$ & $\begin{array}{l}- \\
- \\
-\end{array}$ & $\begin{array}{l}\mathbf{0 . 5 8} \\
0.33 \\
0.69 \\
0.46\end{array}$ & $\begin{array}{c}0.16 \\
- \\
-\end{array}$ & $\begin{array}{r}99.57 \\
99.93 \\
100.00\end{array}$ \\
\hline $\mathrm{BK}-4 / 5$ & $\begin{array}{l}1 \text { core } \\
2 \text { rim } \\
3 \text { rim } \\
\quad \text { Average content }\end{array}$ & $\begin{array}{l}\mathbf{9 9 . 2 8} \\
98.97 \\
98.94 \\
98.59\end{array}$ & $\begin{array}{l}- \\
- \\
-\end{array}$ & $\begin{array}{l}\mathbf{0 . 4 9} \\
0.61 \\
0.53 \\
0.70\end{array}$ & $\begin{array}{c}\mathbf{0 . 0 5} \\
0.13 \\
0.18 \\
-\end{array}$ & $\begin{array}{l}99.71 \\
99.65 \\
99.29\end{array}$ \\
\hline $\mathrm{BK}-5 / 1$ & $\begin{array}{l}1 \text { core } \\
2 \text { rim } \\
3 \text { rim } \\
4 \text { rim } \\
\quad \text { Average content }\end{array}$ & $\begin{array}{l}\mathbf{9 8 . 8 3} \\
99.41 \\
98.72 \\
98.86 \\
\mathbf{9 8 . 9 9}\end{array}$ & $\begin{array}{l}- \\
- \\
-\end{array}$ & $\begin{array}{l}\mathbf{0 . 6 1} \\
0.52 \\
0.78 \\
0.60 \\
\mathbf{0 . 6 3}\end{array}$ & $\begin{array}{c}0.10 \\
- \\
- \\
0.17 \\
0.05\end{array}$ & $\begin{array}{l}99.93 \\
99.50 \\
99.63\end{array}$ \\
\hline $\mathrm{BK}-5 / 2$ & $\begin{array}{l}1 \text { core } \\
2 \text { rim } \\
3 \text { rim } \\
\quad \text { Average content }\end{array}$ & $\begin{array}{l}98.73 \\
98.45 \\
99.35 \\
\mathbf{9 8 . 8 4}\end{array}$ & $\begin{array}{l}- \\
- \\
-\end{array}$ & $\begin{array}{l}0.59 \\
0.53 \\
0.51 \\
\mathbf{0 . 5 4}\end{array}$ & $\begin{array}{c}0.18 \\
0.14 \\
- \\
\mathbf{0 . 1 0}\end{array}$ & $\begin{array}{l}99.50 \\
99.12 \\
99.86\end{array}$ \\
\hline BK-6 & $\begin{array}{l}1 \text { core } \\
2 \text { rim } \\
3 \text { rim } \\
\quad \text { Average content }\end{array}$ & $\begin{array}{l}99.26 \\
98.70 \\
98.54 \\
\mathbf{9 8 . 8 3}\end{array}$ & $\begin{array}{l}- \\
- \\
-\end{array}$ & $\begin{array}{l}0.66 \\
0.41 \\
0.66 \\
\mathbf{0 . 5 7}\end{array}$ & $\begin{array}{c}- \\
0.10 \\
0.23 \\
\mathbf{0 . 1 1}\end{array}$ & $\begin{array}{l}99.92 \\
99.21 \\
99.43\end{array}$ \\
\hline BK-7 & $\begin{array}{l}1 \text { core } \\
2 \text { rim } \\
3 \text { rim } \\
\quad \text { Average content }\end{array}$ & $\begin{array}{l}99.33 \\
98.31 \\
99.46 \\
\mathbf{9 7 . 3 2}\end{array}$ & $\begin{array}{c}- \\
0.25 \\
- \\
\mathbf{1 . 7 4}\end{array}$ & $\begin{array}{l}0.55 \\
0.58 \\
0.72 \\
\mathbf{0 . 3 5}\end{array}$ & $\begin{array}{c}0.10 \\
- \\
0.11 \\
\mathbf{0 . 0 9}\end{array}$ & $\begin{array}{r}99.98 \\
99.14 \\
100.29\end{array}$ \\
\hline Borovik & Average content & 97.38 & 1.64 & 0.55 & 0.10 & \\
\hline
\end{tabular}




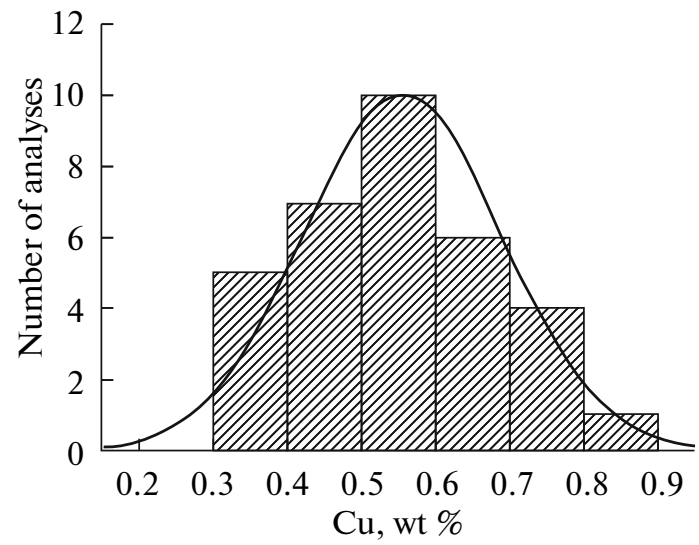

Fig. 3. Histogram of the $\mathrm{Cu}$ content in native gold of the Borovik ore field.

fine grains of native gold are irregular-shaped or isometric, and some grains are complex in shape. Native gold of the Borovik ore field is classified as very fine grains (Fig. 2) according to Petrovskaya (1973). Almost all grains of native gold are characterized by the layered structure (Fig. 2f). The morphology of gold grains (Figs. 2a, 2b, 2c, 2d) allows conclusion that the grains input from primary source (Zakharova, 1994).

Chemical composition of native gold. The electron microprobe data given in table indicate that native gold from the Borovik ore field is extremely high-fineness (up to 999, sample BK-4/3, see table) and belongs to the high-fineness variety (Table). The Ag content in native gold ranges from 0.25 (one grain, sample BK-7) to $12.91 \mathrm{wt} \%$ (sample BK-3, see table). The distribution of $\mathrm{Ag}$ in this grain is zoned: the core is rich in $\mathrm{Ag}$ (up to $12.91 \mathrm{wt} \%$ ) as compared with the rim (7.249.09 wt \%) (table). The similar zoning was established in the native gold from the Plavica and Borov Dol deposits (Volkov et al., 2008; Stefanova et al., 2013). Average $\mathrm{Ag}, \mathrm{Cu}$, and $\mathrm{Fe}$ contents in native gold are, wt \%: $1.64,0.55$, and 0.1 , respectively (see table). The $\mathrm{Cu}$ concentration in some grains of native gold ranges from 0.34 to $0.78 \mathrm{wt} \%$ and is normally distributed (Fig. 3). The Fe content in native gold is low ranging in some grains from 0.03 to $0.28 \mathrm{wt} \%$ (see table).

The results obtained are similar to previously published data on geochemistry of native gold from the Borov Dol porphyry copper and Plavica HS epithermal deposits (Volkov et al., 2008; Stefanova et al., 2013). Native gold of the Borovik ore field is distinguished by higher fineness and higher concentrations of $\mathrm{Fe}$ and $\mathrm{Cu}$. Electrum was found in placer gold neither in the Borovik ore field nor at the adjacent Plavica deposit (Dumurdzanov et al., 2005).

\section{CONCLUSIONS}

Thus, native gold from the Borovik ore field is homogeneous in composition; it is very high-fineness and contains appreciable amounts of $\mathrm{Fe}$ and $\mathrm{Cu}$. The chemical composition does not depend on the grain morphology, which indicates close primary source. The composition and morphology of native gold predict the HS-type epithermal mineralization in the Borovik ore field similar to that at the Plavica deposit. It should be noted that extremely rare published data on typomorphic features of native gold in the ores of porphyry copper and HS-type epithermal deposits (Serafimovsky et al., 2010; Nikolaeva et al., 2008) are consistent with our results.

Pan sampling within porphyry copper and HS epithermal silver-gold deposits and ore fields allows identification and detailed study of the chemical composition and morphological features of native gold from deposits of these types. This procedure is recommended to be applied at prospect and prospect-andevaluation works.

\section{ACKNOWLEDGMENTS}

This study has been supported by the Russian Science Foundation (project no. 14-17-00170).

\section{REFERENCES}

Bogojevski, K. Metallogeny of the tertiary magmatism in the area of Osogovo-Besna Kobila, in: Rep. 6th symp, Skopje. 1967. P. 81-97.

Cifliganec, V., Jankovic S., and Serafimovski, T. Geotectonic setting and metallogenic characteristics of porphyry copper deposits in the Serbo-Macedonian province, Rom. J. Miner. Deposits, 1997, vol. 78, no. 2, pp. 85-92.

Dumurdzanov, N., Serafimovski, T., Burchfiel, B.C. Cenozoic tectonics of Macedonia and its relation to the South Balkan extensional regime, Geosphere, 2005, no. 1, pp. 1-22.

Nikolaeva, L.A., Gavrilov, A.M., Nekrasova, A.N. et al., Generalized guide models of native gold from various ore deposits, Rudy. Met., 2008, no. 3, pp. 62-68.

Petrovskaya, N.V., Samorodnoe zoloto (Native Gold), Nedra Moscow, 1973.

Serafimovskii, T., Stefanova, V., and Volkov, A.V., Dwart copper-gold porphyry deposits of the Buchim-DamjanBorov Dol ore district, Republic of Macedonia (FYROM), Geol. Ore Deposits., 2008, vol. 55, no. 3, pp. 179-195.

Stefanova, V., Volkov, A.V., Serafimovski, T., and Sidorov, A.A., Native gold from the Plavica epithermal deposit, Republic of Macedonia, Dokl. Earth Sci., 2013, vol. 451, no. 2, pp. 818-823.

Volkov, A.V., Stefanova, V., Serafimovskii, T., and Sidorov, A.A., Native gold from the Borov Dol porphyry copper deposit, Republic of Macedonia, Dokl. Earth Sci., 2008, vol. 422, no. 7, pp. 1013-1017.

Zakharova, E.M., Mineralogiya rossypei (Mineralogy of Placers), Nedra, Moscow, 1994.

Translated by I. Baksheev 